\title{
In Search of Inclusive Growth: The Role of Economic Institutions and Policy
}

\author{
Francis Y. Kumah, Mathew Sandy \\ International Monetary Fund, Washington DC, USA \\ Email: fkumah@imf.org,msandy@imf.org
}

Received August 5, 2013; revised September 2, 2013; accepted September 10, 2013

Copyright (C) 2013 Francis Y. Kumah, Mathew Sandy. This is an open access article distributed under the Creative Commons Attribution License, which permits unrestricted use, distribution, and reproduction in any medium, provided the original work is properly cited.

\begin{abstract}
Inclusive economic growth is one of key challenges facing countries across the globe, notwithstanding initial conditions, particularly following the 2008 global economic slowdown. This paper searches for links between the quality of institutions, economic policies, economic growth and employment creation in low-income countries, using the specific case of Sierra Leone to illustrate. While its findings are consistent with the literature, the paper suggests that re-focusing economic policies on per capita real GDP growth may yield employment dividends, but well-targeted interventions would be needed to cater for the unemployed and to support vulnerable groups which may be adversely impacted by the very policies that drive growth.
\end{abstract}

Keywords: Inclusive Growth; Macroeconomic Policy; Economic Institutions; Penalty Function; Job Placement; Absolute Poverty

\section{Introduction}

Following the global economic slowdown in the aftermath of the 2008-09 financial crisis, requests of the Arab Spring are from the youth across the world for voice and viable solutions to their economic plight, and reflecting persistence of unemployment and social exclusion in lowincome countries, governments have begun a search for inclusive growth-i.e. output expansion that generates jobs. This search is supported by the principle that acceleration in economic growth benefits the poorer segments of population so long as it does not worsen the distribution of wealth. In effect, this thinking is based on the idea that economic growth enables the participation of the unemployed and the poor who, through engagement in the production processes that generate growth, will benefit through an absolute increase in their incomes. Thus, according to this thinking, inclusive growth relates to alleviation of absolute poverty, and the increases in growth improve the GINI coefficient in countries (see for example Ianchovichina and Lundstrum [1], and Ravallion and Chen [2], for an absolute definition of pro-poor growth). Put another way, countries with more equal income distributions experience higher economic growth. Despite these hypotheses, the literature on inclusive growth (in excep- tion of the few that we discuss in the next section) has been relatively silent on the role of policies that help sustain economic growth and on those that help generate jobs and provide a social protection floor for the vulnerable.

In order to understand economic growth earlier, research established the following stylized facts relating to the nature and pattern of growth across the globe: 1) there are variations in per capita income across the world, 2 ) the rate of economic growth varies substantially across the world, 3) economic growth rates are not generally constant over time, 4) a country's relative position in the world distribution of per capita income is not immutable - countries can move from being poor to being rich and vice versa, 5) the United States of America has exhibited a steady, sustained growth in per capita income over the past century (except in the aftermath of the recession of 2008), 6) growth in output and growth in volume of international trade (openness) are closely related, and 7) both skilled and unskilled workers tend to migrate from poor to rich countries or regions. In the same vein, Dollar and Kraay [3], find that globalization, openness, and trade help sustain growth and reduce poverty. Thus, the facts on variations in growth patterns have been documented along with the role of policy in sustaining economic growth and reducing poverty. 
However, engineering inclusive growth or embarking on a growth path that generates jobs and helps reduce poverty in Low-Income Countries (LICs) is getting increasingly illusive, particularly as millions of the youths in these countries remain unemployed or underemployed for various reasons, and the duration of unemployment among this group is long and continues to pose challenges to macroeconomic policy. In circumstances such as this, it is not sufficient to just have economic growth year after year; the type of growth which is required is one that engages the youth in gainful employment and provide for the vulnerable - thus helping reduce the potential for social unrest. Thus, supplemental policies may be required to address income inequality and provide for vulnerable groups, such as the aged and the unemployable. The big question, however, is how to do this; how do we achieve inclusive growth? In this paper, we follow the pro-poor growth literature but extend this, using data on Sierra Leone, to empirically identify country-specific circumstances (socio-political history and economic endowments) and policy requirements to attain inclusive growth.

The paper finds that macroeconomic stability supports inclusive economic growth; countries that have reduced inflation variability (and thus, have more stable economic environment) also exhibited higher per capita economic growth rates. In addition, while economic openness helps pro-poor growth, it is necessary to adopt policies that help maintain international competitiveness, particularly in resource-rich countries that may experience real appreciation of their currencies as the resource sector drives wage increases and nominal appreciation of their currencies. Furthermore, credit boom supports economic growth, while stable government consumption supports macroeconomic stability. The paper is organized as follows. The second section discusses earlier findings in the pro-poor or inclusive growth literature, emphasizing the role of economic policy in driving growth and poverty reduction; this section also presents the socio-political background of Sierra Leone. Section 3 outlines the growth accounting model used to estimate total factor productivity (TFP) in the full sample of countries, LICs and SubSaharan Africa countries; Sierra Leone's performance is discussed alongside its peers. In addition, the section presents the empirical econometric model estimated, discussing its main assumptions and the benefits of the panel estimators chosen ${ }^{1}$. Section 4 presents and discusses policy implications of the empirical results and their relevance to Sierra Leone's circumstances. Section 5 summarizes the paper and presents some concluding remarks.

\section{Background and Literature Survey}

The search for inclusive growth and economic policies

${ }^{1}$ The approach adopted here-growth accounting and growth regressions - have been used extensively in the literature; see for example Bosworth and Collins [4] and Hulten [5]. conducive to such growth started with an inquiry into an operational definition of inclusive growth and its characterization. Various researchers have attempted various definitions ranging from pro-poor growth to povertyreducing growth. The approach adopted by these earlier researchers was bedeviled by criticality of the distinction between absolute and relative poverty. Ravallion and Chen [2] put this succinctly as the questions of "how the gains from aggregate economic growth (or losses from contraction) were distributed across households according to their initial incomes or expenditures". Further work into the nature and pattern of growth has revealed that countries that have experienced sustained economic growth have also experienced significant reductions in poverty and income inequality. While most of these findings are based only on analysis of correlation coefficients among relevant variables and do not indicate causality, it is widely documented (see for example Rodrik [6] and Dollar and Kraay [3]) that sustained rapid growth that expands economic opportunities also tends to make society well off - thus reducing absolute poverty. Thus, inclusive growth has come to be defined as growth that enlarges the size of the economy and increases employment opportunities. Attaining this type of growth helps reduce absolute poverty. This is the thrust of the approach we adopt in this paper, particularly since we do not have good indicators for measuring relative poverty, but first, we would like to revisit earlier empirical findings that provide solid foundations for our empirical assumptions.

In a discourse on the impact of economic growth on poverty reduction, Rodrik [6] asserts that absolute poverty has declined in countries that have sustained rapid economic growth in the past decade. He argues that since the GINI coefficient tends to be stable over time in countries, any gains in growth are translated into poverty reduction, and that the relevant question to ask is what types of policies promote growth and reduce poverty. In his view, “... the magnitude of poverty reduction payoff from growth depends, in part, on a country's specific circumstances and policies". Investigating the significance of various policies on economic growth and poverty reduction, Dollar and Kraay [3] found openness to foreign trade, good rule of law and fiscal discipline, and avoidance of inflation to be important drivers. They conclude that "... growth generally does benefit the poor..." and that the quest for poverty reduction should aim at policies that promote growth. Furthermore, they argue for good institutions, the rule of law, and property rights along with political stability (and peace) when they assert that these conditions "... directly create a good environment for poor households to increase their production and income". Indeed, in their analysis of the growthpoverty nexus, Pinkovskiy and Sala-i-Martin [7] indi- 
cated that poverty and GDP per capita in the largest Sub-Saharan African countries during 1970-2009 (Ethiopia, South Africa, Nigeria, and Congo-Zaire) are "mirror images of each other"- - thus, consistent with the findings of Dollar and Kraay [3], policies that promote growth of per capita GDP also help reduce poverty.

We gather from these findings that 1) growth-promoting policies also help alleviate poverty, since the GINI coefficient tends to be constant over time, and that 2) economic policies and quality of institutions do matter in the quest for inclusive growth; just as initial country circumstances (for example, countries just emerging out of war have different challenges from those that have enjoyed long periods of peace) and the nature of the business environment as well as access to credit. These are the factors and considerations that drive the empirical research presented in this paper, using the specific example of Sierra Leone to illustrate the significance of institutions and economic policy.

\section{The Case of Sierra Leone}

Half a century has passed since Sierra Leone attained independence, and it has been a decade since the end of the civil conflict that halted economic activities, but structural impediments and institutional bottlenecks linger and continue to constrain output and employment growth. During the period immediately following independence and before the onset of the civil conflict (a period we dub an era of post-independence gust and vibrancy) Sierra Leone used to be called the Athens of West Africa mainly because it had the oldest university along the Gulf Coast - Fourah Bay College - which served as the hub for tertiary education in English-speaking West Africa. During this period, per capita real GDP growth averaged 4 percent per annum (a high level by regional standards) and inflation averaged 6 percent.

However, by the mid-1970s, adverse terms of trade shocks coupled with build-up of economic pressures in the aftermath of the Organization of African Unity (OAU) summit held in the country eroded productivity, stoked price pressures, and instigated political and civil conflict. Given its buoyant economy, the country was called upon by the African Union to host the OAU summit of heads of state in 1983. Coupled with adverse impact of a decline in iron ore prices in the mid-1970s, the financial decadence that followed the OAU meetings in 1983 eroded these gains even prior to the onset of the civil conflict in 1991. The main iron ore mining company, Delco mines, had to shut down and this triggered deterioration in the balance of payments as well as exchange rate and inflationary pressures that laid the foundations for political instability. During this period - of internalized adverse external shocks - per capita real GDP growth declined by 2 percent per year and inflation averaged 40 percent (Figures 1 and 2).

While per capita real GDP growth declined inflation surged as the local currency depreciated by 24 percent relative to the dollar. The confluence of these factors visited untold hardship on the citizens and, coupled with the onset of the civil conflict in neighbouring Liberia, fueled the civil conflict that raged during 1991-2001-a period of heightened per capita misery.

The civil conflict halted all economic activity, institutions deteriorated and human indicators plummeted. There was a cobweb of coup d'etats in the early 1990s that culminated into a decade-long costly civil conflict. Per capita real GDP declined during this period as productivity sank, and inflation soared. In fact, this was the period of highest inflation, if the period before it is adjusted for the adverse effects of the OAU summit and terms of trade shock; consumer price inflation reached 70 percent in 1991 and averaged 25.5 percent per year, while per capita real GDP growth declined by 7.5 percent per year during the period. The country entered a phase of unprecedented per capita misery as infrastructure and human development suffered massive setback and basic social services disappeared overnight. Productivity growth and social indicators plummeted and Sierra Leone has since trailed behind regional peers on many social indicators (Table 1).

In addition to socio-economic factors described above, weak and unreliable infrastructure, public sector inefficiency, and the absence of the rule of law-particularly during the war years-limited the pace of private sector development, economic growth, and employment generation in Sierra Leone. In particular, the road network, electricity supply, and access to safe drinking water remain severely underdeveloped and unreliable. The road network leading to economically viable areas is in very poor state and most regional towns lack pipe-borne water. These conditions increased the cost of doing business through traffic congestion and interruption in utility services. With the completion of the Bumbuna hydro-electric project in 2009, progress has been made in stepping up power generation and electricity supply, particularly to the capital city, Freetown. However, excess energy demand persists as the over 25-year delay in completing the Bumbuna project meant that energy demand exceeded the generation capacity of the completed phase. In addition, the power distribution capacity is severely hampered by backward transmission and distribution network. As a result, even when there has been an increase in power generation, power distribution remains problematic.

Furthermore, institutional lapses and public sector inefficiency did not augur well for the business environment and economic growth. The main conclusions of Danny Rodrik et al. [8], which underscore the significance of institutions for economic growth, are very pertinent to 


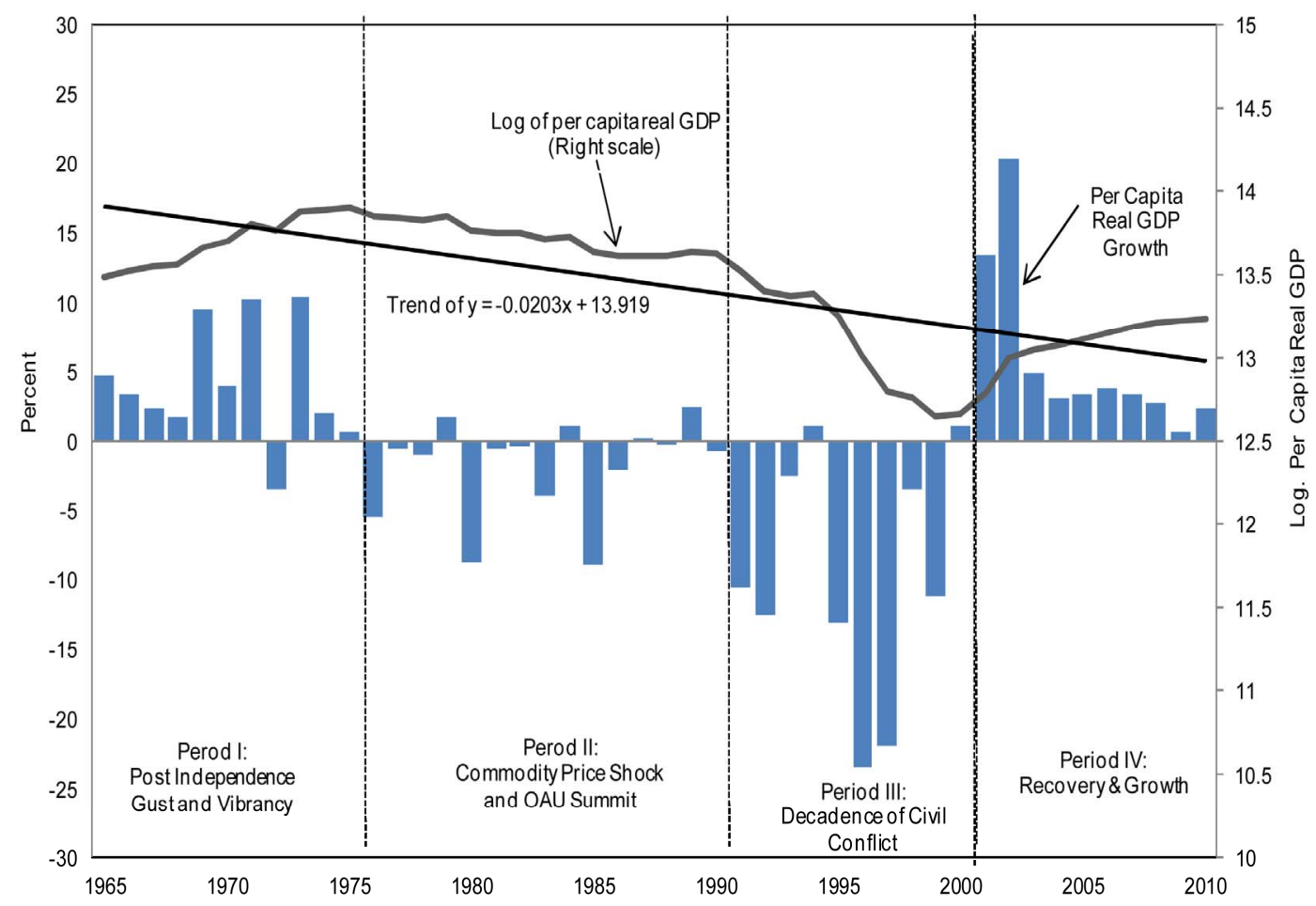

Source: World Economic Outlook, and authors' estimates.

Figure 1. Sierra Leone: Dynamics of per capita real GDP, 1960-2010.

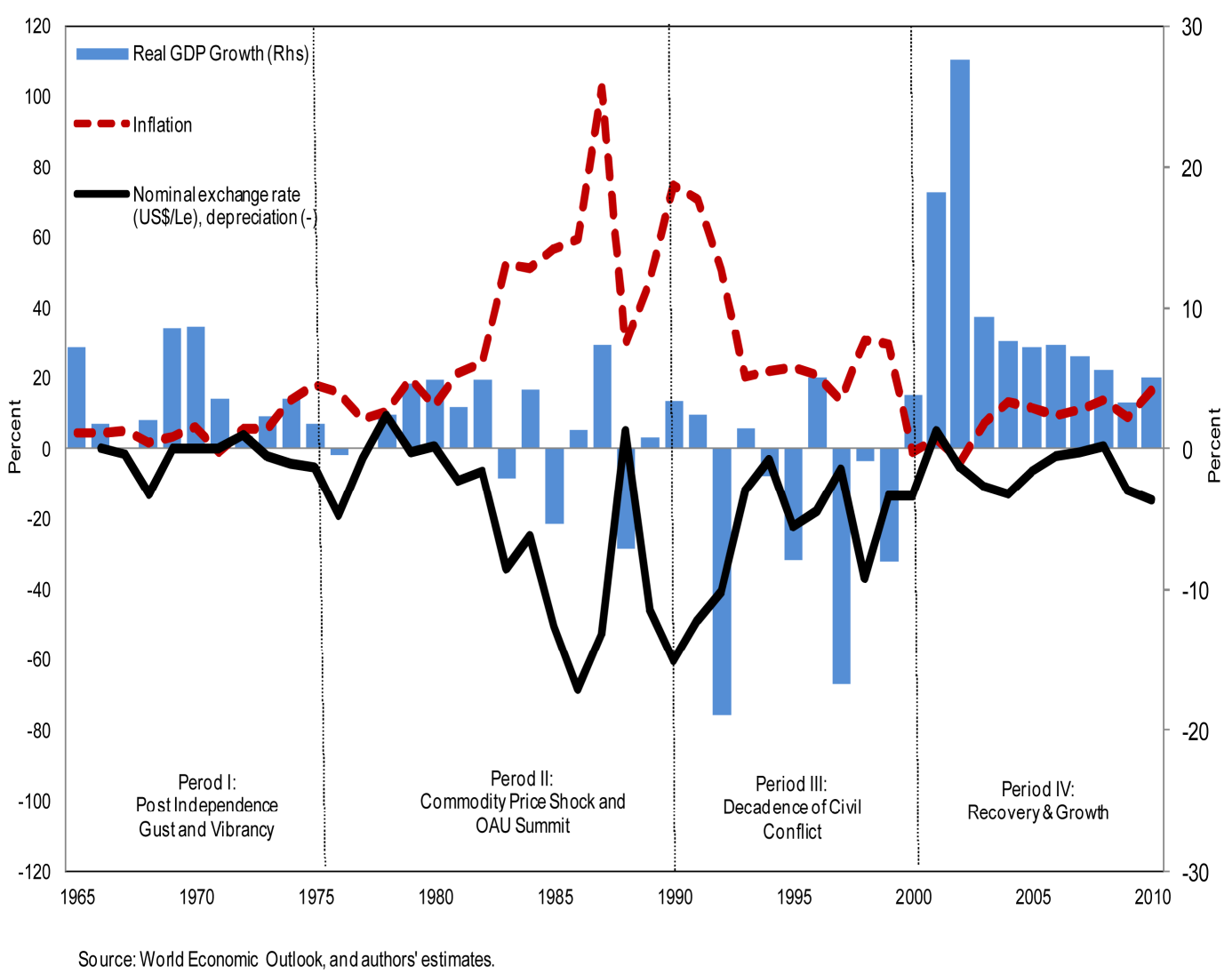

Figure 2. Sierra Leone: Real GDP growth, exchange rate movements, and consumer price inflation, 1960-2010. 
Table 1. Sierra Leone: Selected social indicators, 2000-2010.

\begin{tabular}{cccccc}
\hline \multicolumn{5}{c}{ (In indicated measures)/1 } \\
\hline & Per Capita Income & Human Development Index & Poverty Headcount & Income Distribution & Adult Literacy rate \\
\hline Gambia & 633 & 0.393 & 33.6 & 47.3 & 42 \\
Ghana & 301 & 0.497 & 28.6 & 42.8 & 62 \\
Guinea & 478 & 0.335 & 49.8 & 39.9 & 51 \\
Liberia & 217 & 0.312 & 83.8 & 38.2 & 56 \\
Nigeria & 443 & 0.441 & 65.5 & 45.9 & 58 \\
Sierra Leone & $\mathbf{2 2 8}$ & $\mathbf{0 . 3 0 7}$ & $\mathbf{5 3 . 4}$ & $\mathbf{4 2 . 5}$ & 32.7 \\
Regional Average 2/ & 383 & 0.381 & 52.5 & 42.7 & 51 \\
Sub-Saharan Africa/3 & 576 & 0.418 & 51.8 & 43.2 & 60 \\
\hline
\end{tabular}

Source: World Development Indicators; and authors' estimates. 1) Per Capita Income measures GDP per Capita (at Constant 2000, US\$). Human Development Index measures the composite index (average achievement in the three basic dimensions of human development-a long and healthy life, knowledge and a decent standard of living as prescribed by the United Nations). Poverty Headcount measures the proportion of people that earns less than \$1.25 a day (in PPP terms). Income distribution is measured by the GINI coefficient - the lower the more equal income/wealth distribution. Literacy rate measures percentage of adults aged 15 and above who are literate. 2) Regional average measures the simple average for Gambia, Ghana, Guinea, Liberia, Nigeria and Sierra Leone over the period. 3) The SSA income distribution average was derived by using the regional average; adjusted by the ratio of poverty headcount for regional average and SSA.

Sierra Leone where the incidence of corruption remains high, adherence to the rule of law weak, property rights almost nonexistent, and the public sector capacity remain inadequate to meet the current policy challenges. The push-factors of corruption are evident-high income inequality (with the top 20 percent wealthiest accounting for around two-thirds of the national income), lingering ethnic divisions, weak judicial system, low public sector capacity and a high degree of market failure. A juxtaposition of these factors is reflected in the persistent low ranking of Sierra Leone (except for recent signs of progress in 2011-12) under the public sector management and institutional cluster of the World Bank's Country Policy and Institutional Assessment (CPIA) ${ }^{2}$.

Weak adherence to the rule of law is a particular problem, as it limits private sector growth, economic growth and job creation. While the legal framework has been upgraded to international standards in many areas, their effective application is often lagging behind. For example, the recently established commercial court has not made significant impact on the perception of the public regarding application of the laws of the state. In addition, the increase in diamond royalties, enacted in January 2010, was not implemented in line with the Mines and Mineral's Act 2009 for mining companies until after a year. Further, the legal limits on central bank lending to the government were abandoned for years until recently, while the National Public Procurement Act 2004 is continuously flouted along with other financial management regulations.

\footnotetext{
${ }^{2}$ With an average score of 2.8 compared to the benchmark 3.1 , Sierra Leone's performance under the public sector management and institutional cluster of the CPIA has been below average during 2005-2009. The country's 2011-12 average score for this cluster improved to 3.3, which is within the benchmark average for medium performers.
}

\section{Growth Accounting and Model Specification}

We utilize a growth accounting framework to identify factors that underpin real per capita growth ${ }^{3}$. Following the literature, we use the neoclassical Cobb-Douglas production function:

$$
y_{t}=a_{t} k_{t}^{\alpha}
$$

where $y_{t}$ denotes real output/GDP per capita, $a_{t}$ corresponds to total factor productivity, $k_{t}$ is capital-labor ratio, and $\alpha$ is the share of capital in the production process. Taking natural logarithms through Equation (1), totally differentiating with respect to time and re-arranging yields an expression for total factor productivity as

$$
\frac{\mathrm{d} \log y_{t}}{\mathrm{~d} t}=\frac{\mathrm{d} \log a_{t}}{\mathrm{~d} t}+\alpha \frac{\mathrm{d} \log k_{t}}{\mathrm{~d} t}
$$

which indicates that total factor productivity can be derived as a residual after accounting for the contribution of capital per labor in real per capita output growth. To illustrate this using data, we build capital stock series using the perpetual-inventory method:

$$
K_{t+1}=(1-\delta) K_{t}+I_{t}
$$

with an annual depreciation rate, $\delta$, of 4 percent, while $\alpha$ was set at 33 percent, in line with typical estimates from the literature. This is then divided by the labor stock, $L_{t}$, for each year to yield the capital labor ratio over time. The initial capital stock is calculated as

$$
K_{0}=Y_{0}\left(\frac{g}{\delta+g}\right)\left(\frac{I_{0}}{Y_{0}}\right)
$$

\footnotetext{
${ }^{3}$ We do not intend to give any idea of causality here. The approach has been used in the literature (and in this paper) as "a simple and internally consistent framework for organizing data" that helps "gain valuable insights into the process of economic growth" Hulten [5].
} 
where $Y_{0}$ is initial (1960) output, $I_{0}$ is initial gross fixed investment, $\delta$ is the depreciation rate, and $g$ denotes output growth during 1960-1969.

From Equation (2) we reckon that real per capita output growth is depended not only on the efficiency of capital-labor ratio but also on the productivity (TFP) enshrined in the whole production process. Following the classical approach of Solow (1957), we postulate that the residual from a $y-k$ regression could be interpreted as capturing total factor productivity, which could be dependent in turn on a variety of factors - such as openness of the economy (which expands the resource envelope of a country), the business and institutional environment, macroeconomic policies (the quality of economic institutions and arrangements and of initial policy stance), and access to credit - that have been considered in the literature.

Further, we specify an empirical panel econometric model of the form

$$
y_{i t}=\alpha y_{i, t-1}+\beta k_{i t}+\gamma X_{i t}+\eta_{i}+v_{i t}
$$

where $y_{i t}$ denotes real per capita GDP growth, $k_{i t}$ is the capital-labor ratio, and $X_{i t}$ is a matrix of proxy variables used to capture the effects of total factor productivity. As discussed above, we include in $X_{i t}$ variables such as openness, the real effective exchange rate, an indicator of macroeconomic stability, credit boom and real government consumption. It turns out that inflation variability (defined as the logarithm of the deviation of inflation from the trend in 1960-1970) is a good indicator of macroeconomic stability. Likewise, credit boom (defined/derived as the logarithm of deviations of real private credit from trend) works well as an indicator for access to credit, as increases in this proxy variable has the desired effects on real per capita growth. The variable $\eta_{\text {it }}$ captures unobservable country-specific characteristics, while $v_{i t}$ is an error term with the usual classical assumptions: 1) orthogonality and zero mean

$$
\left(E\left[\eta_{i}\right]=E\left[v_{i t}\right]=E\left[\eta_{i} v_{i t}\right]=0\right)
$$

serial uncorrelatedness

$$
\left(E\left[v_{i t} v_{i s}\right]=0, \text { for } s \neq t\right)
$$

and homoskedasticity or constant variance

$$
\left(E\left[\eta_{i}^{2}\right]=\sigma_{\eta}^{2} \text { and } E\left[v_{i t}^{2}\right]=\sigma_{v}^{2}\right) .
$$

We further assume 1) correlated country-specific effects, or fixed effects such that $E\left[X_{i t} \eta_{i}\right] \neq 0^{4}$; and 2) strict exogeneity $\left(E\left[X_{i t} v_{i s}\right]=0\right.$ for all $\left.s, t\right)$, which rules out feedback effects from past $v_{i s}$ shocks to current $X_{i t}$.

\footnotetext{
${ }^{4}$ This assumption suggests the panel fixed effects estimator as more suitable than the random effects estimator. Indeed, country performance on the elements of the $\mathrm{X}$ variable set is in reality broadly dependent on country circumstances and/or initial conditions.
}

We do expect, a priori and consistent with the theory, $|\alpha|<1$ for stability, and a positive response of real per capita GDP growth to increases in the real capital-labor ratio (i.e. $\beta>0$ ). Economic openness as defined, measures the extent to which a country trades with the rest of the world; by definition therefore, openness is expected to yield additional resources to a country in the form of gains from trade, and hence should increase growth potentials. Real exchange rate appreciation/depreciation reduce/enhance competitiveness of countries and has negative/positive effects on per capita real GDP growth. Further, macroeconomic stability is expected to enhance growth prospects, as it helps predictability and reduces costs to businesses. It cannot be overemphasized that growth of the private sector depends, first and foremost, on access to credit, which in turn, improves growth prospects. On the other hand, excessive real government consumption (i.e. public spending on wages and salaries, transfers and goods and services) only competes with the private sector for limited resources and hence reduces growth as the private sector tends to be crowded out by government spending. These a priori propositions are tested using panel data estimators.

\section{Empirical Specification and Results}

This section summarizes the results from our growth accounting exercise and econometric estimations. While the growth accounting exercise is a preliminary empirical verification of the relationship between real per capita GDP growth, the capital per labor ratio, and productivity growth, the econometric estimates offer broader parametric estimates of $\left(k_{t}-\right.$ and $\left.X_{t}-\right)$ elasticities of real per capita growth, which are policy relevant. In addition to these elasticities, we also investigate the impact of the quality of macroeconomic policy/management and the business environment. This section summarizes the empirical results and draws policy implications and relevance for Sub-Saharan African countries-Sierra Leone in particular.

\subsection{Growth Accounting Results}

The growth accounting framework for all countries for the period 1960-2010 indicates that TFP is an important factor in real per capita output growth (Table 2). For the full sample, real per capita GDP growth averaged 2 percent in 1960-2010, mainly originating from TFP which contributed about 1.5 percentage points to this growth. Per capita growth in low-income countries, including Sub-Saharan African countries, averaged 1 percent during the same period, with the bulk contribution originating from capital accumulation.

While we observe a positive association of the contribution of TFP and real per capita growth in all country 
Table 2. Growth accounting, 1960-2010.

\begin{tabular}{cccc}
\hline & Per Capita & \multicolumn{2}{c}{ Contribution of: } \\
\cline { 3 - 4 } & $\begin{array}{c}\text { Real GDP } \\
\text { Growth }\end{array}$ & Capital Stock & $\begin{array}{c}\text { Total Factor } \\
\text { Productivity }\end{array}$ \\
\hline Full Sample & 2.01 & 0.55 & 1.46 \\
Advance Economies & 3.22 & -0.04 & 3.26 \\
Middle Income Countries & 2.22 & 0.89 & 1.33 \\
Low Income Countries & 1.14 & 0.69 & 0.45 \\
Sub-Saharan Africa & 1.09 & 0.65 & 0.43 \\
$\quad$ Countries & & 0.81 & -1.04 \\
Sierra Leone & -0.24 & 0.84
\end{tabular}

Source: IMF World Outlook (WEO) database; and authors' estimates.

groupings, the results for Sierra Leone show a decline in TFP contribution despite capital accumulation; real per capita output shrunk as TFP declined despite capital accumulation, particularly during the civil conflict in the late 1990s (Figure 1). This result indicates the significance of integrating capital accumulation with capacity building and improvements in basic services to support the production process.

\subsection{Econometric Results}

To empirically investigate the magnitude and significance of capital accumulation to growth in the absence of institutions and macroeconomic policy, we estimate a restricted form of Equation (5) where $X_{i t}$ is set to be a null set or containing only an openness variable. The latter assumption was made to capture the resource augmenting impact of opening up an economy. Specifically, we anticipate that, given the quality of institutions, initial conditions (such as the incidence of political unrest or civil war that disrupted orderly economic activity in parts of the period), and macroeconomic policy, openness extends the resource frontier of countries bringing these countries into contact with more efficient technology and assistance in the form of aid or gains from trade. Two econometric estimators were adopted. The simple fixed effects approach was complemented by the first-differenced GMM approach of Arellano and Bond [9] to address concerns and biases due to endogeneity of openness and capital stock.

Based on country groupings indicated in Table A2 and variable definitions provided in Table A3, the results summarized in Table $\mathbf{3}$ indicate the following:

- Capital stock elasticity of real per capita growth is higher for SSA countries and LICs $(0.05-0.06)$ than for the full sample (0.02). This supports the theoretical proposition of increasing returns on capital at lower levels of capital accumulation; and

- Openness stimulates per capita real GDP growth. The results indicate that more open countries tended to have experienced higher real GDP per capita growth during the period 1960-2010;
These results lead us to investigate the impact of other factors on the magnitude of capital elasticity of economic growth; more specifically, the question we seek to answer is whether capita accumulation alone is sufficient to support inclusive growth-alternatively, do initial conditions, quality of institutions, and economic policy matter? To answer this question, we replace the openness variable in $X_{i t}$ with more active policy variables such as the real effective exchange rate, inflation variability, increases in private sector credit (or episodes of credit boom), and government consumption. All these variables are expressed in logarithms and so their respective coefficients in estimates of Equation (5) indicate elasticities or responses of economic growth (or inclusive growth) to policy. We also investigate the role of the quality of institutions. The empirical results are summarized in two parts - the role of (a) macroeconomic policy, and (b) quality of institutions:

1) Sound macroeconomic policies drive real per capita output growth

The impact of macroeconomic policy (or stability) on inclusive growth is captured through an inflation viability indicator which is estimated as the logarithm of the squared deviations of inflation from the trend established in the 1960s. It turns out that attaining macroeconomic stability improves growth performance in all samples considered. In particular, countries that reduced inflation variability through appropriate macroeconomic policies gained on inclusive growth - the elasticity, albeit small, is highly significant and consistent with a priori expectations of the effectiveness of macroeconomic policy.

Macroeconomic theory predicts that real exchange rate movements (through variations in the nominal exchange rate or inflation or some combinations of these) do influence the trade balance via the Marshall-Lerner condition, and subsequently on economic growth. In particular, exchange rate appreciations tend to adversely affect the trade balance and growth. Our empirical findings summarized in Table 4 are consistent with these theoretical predictions, which underscore the need for inflation control along with awareness about the impact of nominal exchange rate movements, particularly in natural resource rich countries, such as Sierra Leone, where large inflows into the mining sector might lead to nominal appreciation of the domestic currency while driving a wedge between wages in the tradable and nontradable sectors of the economy.

Availability of finance (defined in this paper to reflect credit booms or deviations of private credit/GDP ratio from the trend in the 1960s) helps finance private sector economic activity and boosts growth and employment. While our empirical results for all low-income countries are consistent with this proposition, SSA countries exhibit a perverse result where increases in credit (or credit 
Table 3. Panel (fixed effects and GMM) estimates of per capita real GDP equations, 1960-2010.

\begin{tabular}{|c|c|c|c|c|c|c|}
\hline \multicolumn{7}{|l|}{ Dependent variable: log. Real GDP per capita } \\
\hline & \multicolumn{2}{|c|}{ Full Sample } & \multicolumn{2}{|c|}{ Low Income } & \multicolumn{2}{|c|}{ SSA } \\
\hline & $\mathrm{FE}$ & $\begin{array}{c}\text { GMM-DIFF } \\
(\mathrm{t}-2)\end{array}$ & $\mathrm{FE}$ & $\begin{array}{c}\text { GMM-DIFF } \\
(\mathrm{t}-2)\end{array}$ & FE & $\begin{array}{c}\text { GMM-DIFF } \\
(\mathrm{t}-2)\end{array}$ \\
\hline \multirow[t]{2}{*}{ One-period lagged per capita real GDP } & $0.9300^{* * *}$ & $0.9554^{* * *}$ & $0.9260^{* * *}$ & $0.9105^{* * *}$ & $0.9361^{* * *}$ & $0.9221^{* * *}$ \\
\hline & $(0.000)$ & $(0.000)$ & $(0.000)$ & $(0.000)$ & $(0.000)$ & $(0.000)$ \\
\hline \multirow[t]{2}{*}{ Capital stock } & $0.0215^{* * *}$ & $0.0211^{* *}$ & $0.047^{* * *}$ & $0.0539^{* * *}$ & $0.0529^{* * *}$ & $0.0627^{* * *}$ \\
\hline & $(0.007)$ & $(0.005)$ & $(0.000)$ & $(0.000)$ & $(0.024)$ & $(-0.002)$ \\
\hline \multirow[t]{2}{*}{ Openness } & $0.0041^{* * *}$ & 0.0062 & $0.0057^{* * *}$ & $0.0070^{* * *}$ & $0.0065^{* * *}$ & $0.0077^{* * *}$ \\
\hline & $(0.000)$ & $(0.000)$ & $(0.007)$ & $(-0.002)$ & $(0.012)$ & $(-0.002)$ \\
\hline \multirow[t]{2}{*}{ Constant } & $0.3128^{* * *}$ & & $0.6604^{* * *}$ & & $0.5483^{* * *}$ & \\
\hline & $(0.000)$ & & $(0.000)$ & & $(0.003)$ & \\
\hline Number of observations & 2,633 & 3.016 & 845 & 987 & 773 & 824 \\
\hline R-squared & 0.9709 & & 0.9349 & & 0.9650 & \\
\hline F statistic & 5.419 .97 & 6.447 .71 & 2.069 .32 & 1.978 .41 & 4.376 .57 & 3.933 .91 \\
\hline Prob $>F$ & 0.0000 & 0.0000 & 0.0000 & 0.0000 & 0.0000 & 0.0000 \\
\hline Hansen test (prob.) & & 1.0000 & & 1.0000 & & 1.0000 \\
\hline $\mathrm{m}(1)$ & & 0.0000 & & 0.0000 & & 0.0010 \\
\hline $\mathrm{m}(2)$ & & 0.0030 & & 0.2940 & & 0.2320 \\
\hline
\end{tabular}

Source: IMF World Economic Outlook (WEO) database; and authors' estimations using panel methods in Stata. Notes: All variables are expressed in logarithms. Figures in parenthesis are probability values; note: ${ }^{* * *} \mathrm{p}<0.01,{ }^{* *} \mathrm{p}<0.05,{ }^{*} \mathrm{p}<0.1$.

Table 4. Panel (fixed effects) estimates of per capita real GDP equations, 1960-2010.

\begin{tabular}{|c|c|c|c|c|c|c|c|c|c|}
\hline \multicolumn{10}{|l|}{$\begin{array}{l}\text { Dependent variable: log. } \\
\text { Real GDP per capita }\end{array}$} \\
\hline \multirow{4}{*}{$\begin{array}{l}\text { One-period lagged per } \\
\text { capita real GDP }\end{array}$} & & Model I & & & Model II & & & Model III & \\
\hline & Full Sample & Low Income & SSA & Full Sample & Low Income & AFR & Full Sample & Low Income & SSA \\
\hline & $0.929^{* * *}$ & $0.903^{* * *}$ & $0.918^{* * *}$ & $0.935^{* * *}$ & $0.895^{* * *}$ & $0.916^{* * *}$ & $0.926^{* * *}$ & $0.884^{* * *}$ & $0.907^{* * *}$ \\
\hline & $(0.000)$ & $(0.000)$ & $(0.000)$ & $(0.000)$ & $(0.000)$ & $(0.000)$ & $(0.000)$ & $(0.000)$ & $(0.000)$ \\
\hline Capital stock & $\begin{array}{l}0.051^{* * *} \\
(0.001)\end{array}$ & $\begin{array}{l}0.036^{* *} \\
(0.001)\end{array}$ & $\begin{array}{l}0.063^{* *} \\
(0.035)\end{array}$ & $\begin{array}{l}0.049^{* * *} \\
(0.003)\end{array}$ & $\begin{array}{l}0.036^{* * *} \\
(0.002)\end{array}$ & $\begin{array}{l}0.065^{* *} \\
(0.035)\end{array}$ & $\begin{array}{l}0.051^{* * *} \\
(0.012)\end{array}$ & $\begin{array}{l}0.035^{* * *} \\
(0.005)\end{array}$ & $\begin{array}{l}0.074^{* * *} \\
(0.050)\end{array}$ \\
\hline \multicolumn{10}{|l|}{ Openness } \\
\hline Inflation variability & $\begin{array}{c}-0.002^{* * *} \\
(0.000)\end{array}$ & $\begin{array}{c}-0.003^{* * *} \\
(0.062)\end{array}$ & $\begin{array}{c}-0.003^{* *} \\
(0.037)\end{array}$ & $\begin{array}{c}-0.002^{* * *} \\
(0.000)\end{array}$ & $\begin{array}{c}-0.002^{* *} \\
(0.089)\end{array}$ & $\begin{array}{c}-0.003^{* *} \\
(0.048)\end{array}$ & $\begin{array}{c}-0.001^{* * *} \\
(0.044)\end{array}$ & $\begin{array}{c}-0.0001 \\
(0.930)\end{array}$ & $\begin{array}{c}-0.0014 \\
(0.436)\end{array}$ \\
\hline REER & $\begin{array}{l}-0.001^{*} \\
(0.262)\end{array}$ & $\begin{array}{c}-0.004^{* * *} \\
(0.015)\end{array}$ & $\begin{array}{c}-0.0012 \\
(0.887)\end{array}$ & $\begin{array}{l}-0.002^{*} \\
(0.157)\end{array}$ & $\begin{array}{c}-0.004^{* *} \\
(0.024)\end{array}$ & $\begin{array}{c}-0.0006 \\
(0.869)\end{array}$ & $\begin{array}{c}-0.0013 \\
(0.222)\end{array}$ & $\begin{array}{c}-0.0022 \\
(0.217)\end{array}$ & $\begin{array}{r}-0.0007 \\
(0.787)\end{array}$ \\
\hline Credit boom & & & & $\begin{array}{l}0.0022 \\
(0.532)\end{array}$ & $\begin{array}{l}0.0003 \\
(0.958)\end{array}$ & $\begin{array}{c}-0.0011 \\
(0.803)\end{array}$ & $\begin{array}{l}0.0022 \\
(0.603)\end{array}$ & $\begin{array}{c}-0.0009 \\
(0.850)\end{array}$ & $\begin{array}{l}-0.0031 \\
(0.533)\end{array}$ \\
\hline Government consumption & & & & & & & $\begin{array}{l}0.017^{*} \\
(0.053)\end{array}$ & $\begin{array}{l}0.028^{* * *} \\
(0.001)\end{array}$ & $\begin{array}{l}0.0123 \\
(0.406)\end{array}$ \\
\hline Constant & $\begin{array}{l}0.684^{* * *} \\
(0.000)\end{array}$ & $\begin{array}{l}0.975^{* * *} \\
(0.000)\end{array}$ & $\begin{array}{c}0.789^{* * *} \\
(0.002)\end{array}$ & $\begin{array}{c}0.626^{* * *} \\
(0.000)\end{array}$ & $\begin{array}{l}1.061^{* * *} \\
(0.000)\end{array}$ & $\begin{array}{l}0.809^{* * *} \\
(0.002)\end{array}$ & $\begin{array}{c}0.685^{* * *} \\
(0.001)\end{array}$ & $\begin{array}{l}1.092^{* * *} \\
(0.000)\end{array}$ & $\begin{array}{c}0.849^{* * *} \\
(0.005)\end{array}$ \\
\hline Number of observations & 2010 & 437 & 437 & 1773 & 417 & 420 & 1324 & 363 & 351 \\
\hline R-squared & 0.9760 & 0.913 & 0.9671 & 0.973 & 0.9048 & 0.9666 & 0.974 & 0.9111 & 0.9673 \\
\hline F statistic & 5.725 .94 & 737.14 & 10.323 .60 & 4.744 .56 & 542.08 & 9.601 .23 & 5487.79 & 599.52 & 8415.89 \\
\hline Prob $>F$ & 0.0000 & 0.0000 & 0.0000 & 0.0000 & 0.0000 & 0.0000 & 0.0000 & 0.0000 & 0.0000 \\
\hline
\end{tabular}

Source: IMF World Economic Outlook (WEO) database; and authors' estimations using panel methods in Stata. Notes: All variables are expressed in logarithms. Figures in parenthesis are probability values; note: ${ }^{* * *} \mathrm{p}<0.01,{ }^{* *} \mathrm{p}<0.05,{ }^{*} \mathrm{p}<0.1$.

boom) do reduce real per capita growth. This may be due to interaction of the dependent variable with the incidence of high nonperforming loans in some SSA countries and prevents effective realization of the positive effects of credit availability. Further research would be needed to investigate the relationship between credit and growth in SSA countries taking into account the effect of financial sector health generally. 
Further, we plot two indicators of macroeconomic policy (the CPIA indicator on overall macroeconomic management and our inflation variability indicator) against per capita real GDP to get insights into the role of macroeconomic policy in promoting inclusive growth. The results depicted in Figure 3 further strengthen our findings from the econometric exercise. Specifically: 1) countries that have made good progress on overall macroeconomic management, culminating into higher average CPIA scores in 2005-2009 also showed high average per capita real GDP growth in 1960-2010. This finding runs through for all country samples considered - the full sample (in row 1), sample of LICs (in row 2), and SSA countries (in the last row); and 2) macroeconomic stability promotes inclusive growth - the charts in the second column of Figure 3 confirm this with a negative slope between average inflation variability and per capita real GDP growth in 1960-2010. Compared with other countries in the full sample as well as in the sample of LICs, SSA countries did not seem to have reaped the growth dividend from improving macroeconomic performance (Figure 3). Almost all SSA countries tended to have lower average per capita real GDP growth rates than their peers even though they scored well on both indicators. This underscores the significance of initial conditions and the requirement of benign combination of factors and conditions for the full benefits of growth to be reaped. For example, what would be the impact of good macroeconomic management in the presence of constraining infrastructure bottlenecks and capacity shortfalls? This is borne out by the performance of Sierra Leone, as the country scored very high on both indicators but had a relatively lower average rate of per capita real GDP growth even among peer SSA countries with similar levels of macroeconomic performance (third row of Figure $3)^{5}$.

2) Quality of economic institutions matter

To avoid entering into the complexities of the nature of the interaction of institutions with economic factors and initial conditions (such as previous adverse or benign socio-political and/or economic conditions) ${ }^{6}$, we regroup all our country samples into subgroups of above and be-

\footnotetext{
${ }^{5}$ Prior to the civil conflict Sierra Leone was referred to as the Athens of West Africa-supplying education and skilled labor to the sub-region. The country boasts of one of the oldest universities south of the Sahara-Fourah Bay College.

${ }^{6}$ Initial conditions have received much attention in the literature, but their characterization of the elements/factors - including colonial origins (Acemoglu et al. [10], the slave trade (Nunn [11]), and geography (Bloom and Sachs [12], and-differ from our use of the term. Consistent with our view, some researchers (such as Fosu [13] use past policy regimes to proxy initial conditions. In this literature, such past policy regimes or "policy syndromes" are defined to include state controls, adverse redistribution, suboptimal intertemporal resource allocation, and state breakdown or war and civil conflict. Bosworth et al. [4] define initial conditions to include population growth, geography, institutional quality and initial per capita income.
}

low average performers on the World Bank CPIA indicators for quality of structural policies, business environment, and overall macroeconomic management. We then run panel fixed effects regressions for these subgroups to ascertain whether there are any significant elasticities in estimated elasticities. The results are summarized in Appendix 3, Tables A4-A6. Based on these results we derive the total policy effects on inclusive growth of a ten-percent improvement in the quality of policy (i.e. in macroeconomic stability, government consumption and the real effective exchange rate). Improvements in macroeconomic stability and the real effective exchange rate are here interpreted as reductions or stability in inflation variability and the real effective exchange rate, while improvements in government consumption are increases in government current spending that do not crowd out the private sector or introduce inefficiencies that reduce the production possibilities frontier.

We introduce a simple penalty function to capture the total effects of these policy changes on inclusive growth. The penal aspect comes in where the sign of a coefficient deviates from its apriori theoretical expectations. We specify the simple penalty function

$$
\varphi_{p}=\alpha \sum_{k=1}^{n} \omega_{k} \hat{\mu}_{k}+\sigma \sum_{k=1}^{n} g\left(c_{k}(p)\right)
$$

where

$$
g\left(c_{k}(p)\right)=\left\{\begin{array}{l}
0 \text { if } \operatorname{sign}\left(\hat{\mu}_{k}\right) \text { is theory inconsistent } \\
\hat{\mu}_{k} \text { if } \operatorname{sign}\left(\hat{\mu}_{k}\right) \text { is consistent with theory }
\end{array}\right.
$$

$\alpha$ is a chosen percent change in the policy variable, $p$; $\omega$ denotes the weight of the policy variable; $\sigma$ is the penalty coefficient (in this example, we set this to 10 , the percent increase in the policy variable); and $\mathrm{k}(=1,2, \ldots, \mathrm{n})$ is the number of policy variables.

The results from implementing this simple penalty function using the panel fixed effects estimates reported in Appendix 3, Tables A4-A6 and setting $\omega$ to 1 for all the policy variables considered reveal that the quality of structural reforms, the business environment, and of overall macroeconomic management do matter for economic growth - and job creation (Figure 4).

Specifically, total policy impact in countries that scored well (i.e. above average) on the World Bank's CPIA sub-modules on these indicators is higher than the baseline (where no distinction is made regarding the quality of institutions and policy implementation) and across all country groupings, except in low-income countries (on all three indicators) and SSA countries (on the structural policies indicator). Thus, for SSA countries for example, the difference in the policy impact of a 10 -percent improvement in the chosen policy variables varies by as much as 9 percentage points and 2 percentage points above the baseline impact, for quality of the 

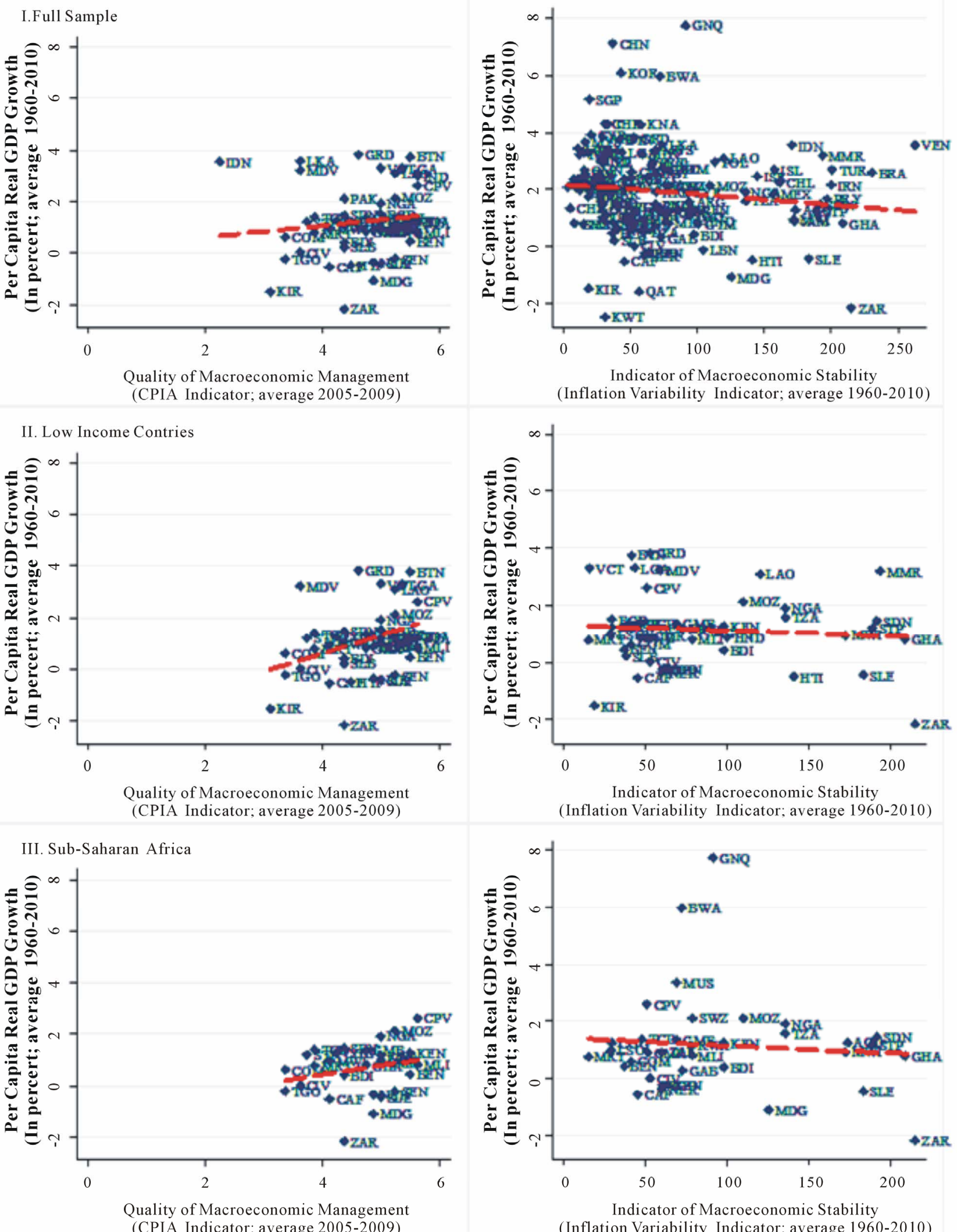

(Inflation Variability Indicator; average 1960-2010)

Source: IMF World Economic Outlook; and authors'calculations.

Figure 3. Per capita real GDP growth and quality of macroeconomic policy, 1960-2010. 

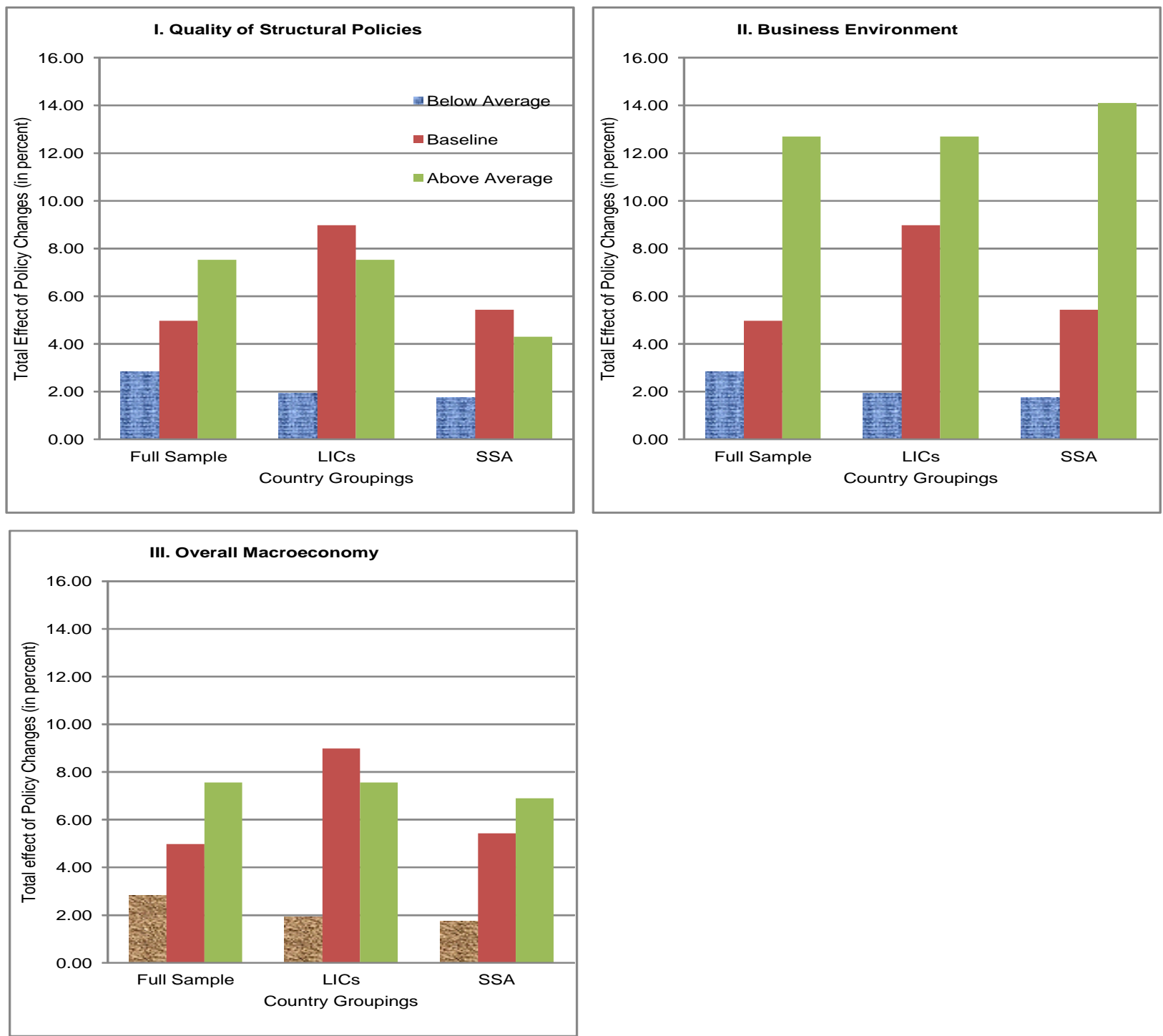

Source: IMF's World Economic Outlook; and authors' estimates based on panel fixed effects estimates of coefficients.

\section{Figure 4. Estimated effects of policy changes.}

business environment and overall macroeconomic management, respectively.

These results are corroborated in broader terms by Figure 5, which reveals the significance of structural reforms and the quality of the business environment for real per capita GDP growth for all country groupings considered. The positive slope of the estimated trend line confirms this observation. Further, and similar to the results in the section above, almost all SSA countries fall below the average performance for their peers that scored similarly on the business environment indicator and the structural policies indicator. Again, this may indicate the absence of necessary ingredients such as peace, basic infrastructure, and human capacity. It is therefore no surprise that Sierra Leone, which has been through a decade of civil conflict that devastated basic infrastructure and halted progress in building human capacity, experienced even lower average per capita real GDP growth rate during the period even among its peer SSA countries that scored similar levels of quality of the business environment (such as Cote d'Ivoire and Mozambique) and progress on structural reform (Cote d'Ivoire and Niger).

\subsection{Policy Implications}

Policy implications emerging from the analysis could be divided into two: direct and indirect (or associated) implications. While the latter emanate from the enhanced effectiveness of policy that is associated with maintain-ing good progress on structural policies/reforms that enhance institutional efficiency and thereby boost the im- 
I. Full Sample

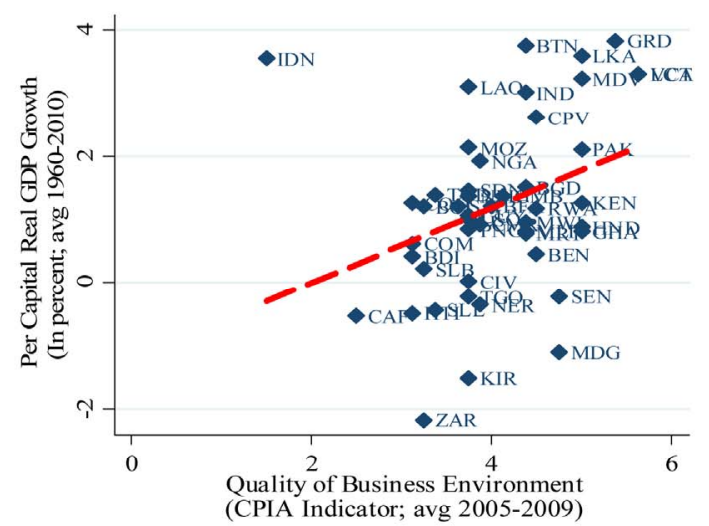

II. Low Income Countries

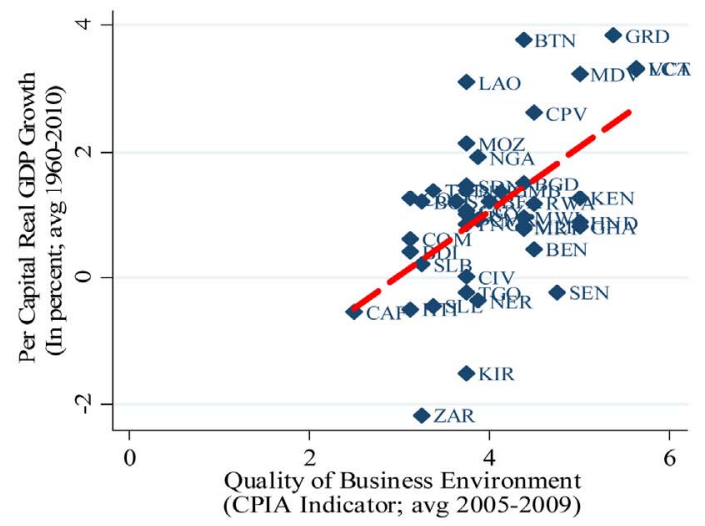

III. Sub-Saharan Africa

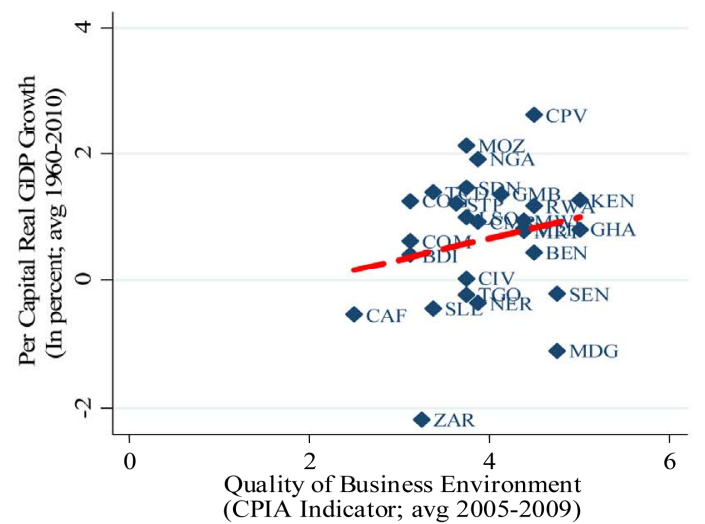

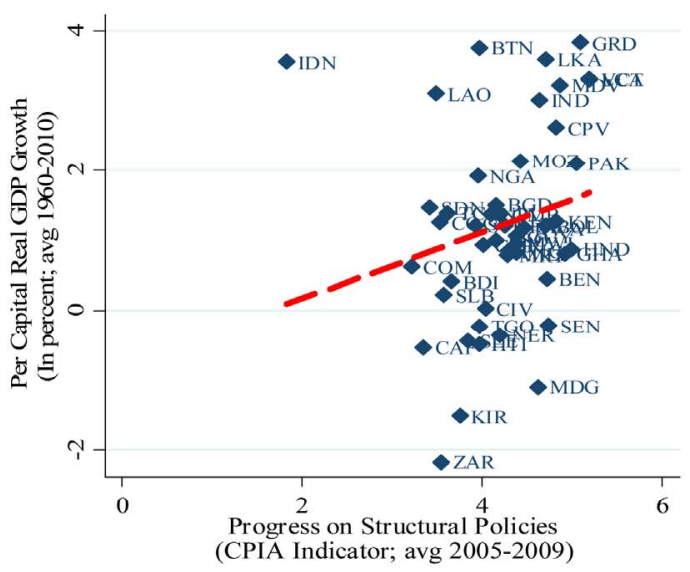
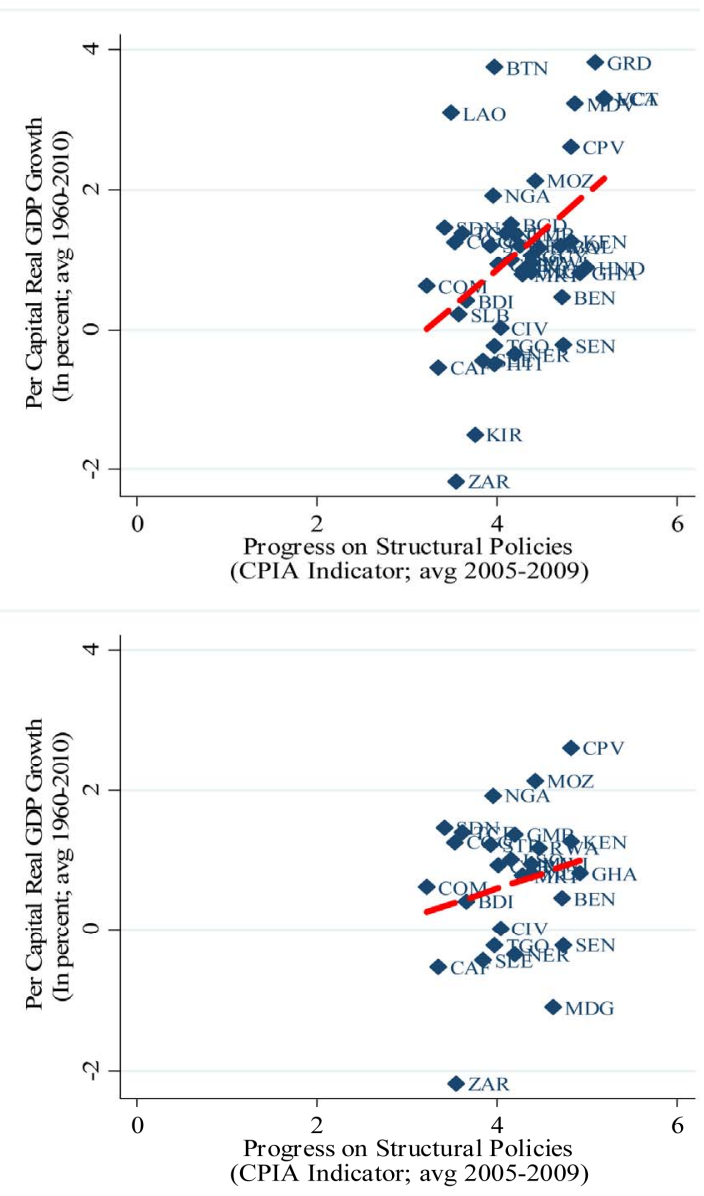

Source: IMF World Economic Outlook; and authors' calculations.

Figure 5. Per capita real GDP growth and structural reforms, 1960-2010.

pact of policy changes on inclusive growth, the former are the direct multipliers from the basic fixed effects estimates. In particular, the results underscore the following:

- pursuance of policies that promote macroeconomic stability is an essential tool in the search for inclusive growth;
- while opening up the economy helps expand the resource envelop for development and inclusive growth, evolution of the real exchange rate should be watched in order to ensure continued external competitiveness;

- access to credit is essential for inclusive growth, but excessive credit booms should be watched to ensure financial stability; and 
- progress on structural reforms that enhance efficiency of public institutions boost policy effectiveness and inclusive growth; so do improvements in the business environment.

Thus, while capital accumulation is essential for economic growth, supporting economic policies and institutional and business environment are equally important.

\subsection{Relevance for Macroeconomic Policy in Sierra Leone}

The search for inclusive growth in Sierra Leone has to incorporate stylized facts from the literature: while capital accumulation and the pursuit of macroeconomic stability are important, the quality of institutions and economic policy do matter. Dividends from steadfast pursuit of macroeconomic stability cannot be overemphasized. Not only does it help maintain the value of money (and dampen the burden of instability on the poor in society) but it also helps maintain a stable and predictable economic environment for private sector planning and operations that go to boost economic growth and employment. In addition, Sierra Leone, as in most LICs (although initial conditions and the nature of policy challenges may differ across countries) structural impediments to growth-1) weak and unreliable infrastructure; 2) institutional weaknesses; and 3) low quality of human capital - should be addressed through deep-going reforms. At the same time, effective sectoral policies would be required, particularly in agriculture and mining, to promote economic activity and create jobs.

Low quality of human capital does not only limit labor's employment opportunities in the private sector but it also constraints public sector capacity. Public service delivery is weakened by the brain drain experienced during the conflict, which resulted in the recruitment of a large number of low-skilled labor force motivated by a poor political agenda. Furthermore, the drop in educational standards and skills mismatch limits the capacity of new graduates in filling the capacity gap. As a result, there remains a huge capacity gap in the public sector and most of the technical jobs are secured by local and foreign consultants. This has warranted the need for urgent civil service reform in order to enhance capacity for implementing the poverty reduction strategy. Some efforts have been made under the Free Healthcare Initiative with the increment of the salaries for healthcare workers in 2010, but much remains to be done in other sectors, particularly within the context of the new initiative to comprehensively reform public sector pay structure to promote the attractiveness of public sector employment. The pay reform agenda of government is expected to address the overhang from the period of near irrational employment in the public sector. Specifically, the reform is expected to be implemented over a five-year period (2011-2015) with the following features: a) minimum wage pay policy, b) classification of jobs into job elements, c) a composite clean wage structure, and d) a unified single spine salary structure ${ }^{7}$.

Building human capacity and addressing infrastructure bottlenecks would help boost TFP and hence per capita real GDP growth and job creation. For now, total factor productivity remains negative and two sectors (agriculture and mining) continue to dominate economic activities. Except for recent boom in FDI for iron ore mining in 2009-2012, private sector participation in economic activity remains generally low across all sectors of the economy mainly on account of the high cost of doing business and other public sector inefficiencies.

A robust social safety net and employment-enhancing labor market policies would be necessary. While specific labor market initiatives such as on-the-job training and job placements for qualified but unemployed youth would help enhance the chances of employment and employability and promote inclusive growth, well-targeted social support or safety net would ensure access to a decent (albeit minimum) living standard for all citizens.

\section{Concluding Remarks}

Following the 2008 financial crisis and subsequent global economic slowdown, many economies have weakened and unemployment has soared. These developments have heightened the search for economic policies to help recovery of the global economy, create jobs, and reduce poverty. The academic literature that resulted from this search has documented the employment elasticity of growth (although broadly unable to estimate these elasticities for most countries because of lack of data) and underscored the role of economic institutions and policy. This paper builds on this literature by investigating the role of institutions and economic policies in promoting inclusive economic growth in low-income countries, with particular emphasis on Sub-Saharan Africa countries. It uses the case of Sierra Leone to illustrate the impact of initial conditions (such as civil conflict or war), institution building and pursuit of macroeconomic stability on per capita real GDP growth - and by implication, job creation. Analysis of the impact of economic growth on poverty reduction follows the literature in assuming that, to the extent that the GINI coefficient changes but gradually, any increases in income resulting from economic growth would benefit all income groups - thus, economic growth creates jobs and reduces poverty.

The paper uses a growth accounting setup comple-

${ }^{7}$ Since the end of the civil conflict, Sierra Leone's public sector reform agenda has been supported by four donors - the World Bank, DFID, the European Union and UNDP. The latest support was three-year project ap proved by the World Bank in May 2012 under the Sierra Leone Pay and Performance Project. 
mented with a panel econometric analysis of main factors that drive inclusive growth. Following the literature, the paper considers the significance of capital accumulation, economic openness and evolution of the real exchange rate, macroeconomic stability, access to credit, government spending, and the quality of economic institutions. It turns out that while capital accumulation is necessary for inclusive growth, it is not sufficient; the quality of economic institutions and economic policy matter. Deriving jobs from economic growth and making a dent into poverty in LICs would also require sector-specific policies, including labor market initiatives with emphasis on job placement and social support. This is a great lesson for fragile states, such as Sierra Leone, who has just emerged from civil conflict or war conditions that have devastated institutional and physical infrastructure, as we have demonstrated in this paper.

Although this paper contributes immensely to the existing literature in the areas outlined above, research challenges remain, which open up a vast opportunity for further work. These challenges border on deriving robust employment elasticities of economic growth, particularly in LICs with data shortcomings, without too much reliance on the assumption of short-term stickiness of the GINI coefficient. Addressing this challenge would be a natural extension of this paper.

\section{REFERENCES}

[1] I. Elena and S. Lundstrum, "Inclusive Growth Analytics: Framework and Application," Policy Research Working Paper, No. 4851, World Bank, 2009.

[2] Ravallion and Chen, "Pro-Poor Growth: A Primer," Development Research Group, World Bank, 2003.

[3] D. Dollar and A. Kraay, "Trade, Growth and Poverty," Development Research Group, Country Policy and Institutional Assessment, World Bank, 2001.
[4] B. P. Bosworth and S. M. Collins, "The Empirics of Growth: An Update," Brookings Papers on Economic Activity, No. 2, 2003, pp. 113-179. http://dx.doi.org/10.1353/eca.2004.0002

[5] C. R. Hulten, "Total Factor Productivity: A Short Biography," In: C. Hulten, E. R. Dean and M. Harper, Eds., New Developments in Productivity Analysis, Studies in Income and Wealth, Vol. 63, Chicago University Press, Chicago, 2001, pp. 1-54.

[6] D. Rodrik, "Growth versus Poverty Reduction: A Hollow Debate," Finance and Development, 2000, pp. 8-9.

[7] M. Pinkovskiy and X. Sala-i-Martin, “African Poverty Is Falling Much Faster Than You Think!” NBER Working Paper, No. 15775, 2010.

[8] D. Rodrik, A. Subramanian and F. Trebbi, "Institutions Rule: The Primacy of Institutions over Integration and Geography in Economic Development," IMF Working Paper No. 02/189, 2002.

[9] M. Arellano and S. R. Bond, "Some Tests of Specification for Panel Data: Monte Carlo Evidence and an Application to Employment Equations," Review of Economic Studies, Vol. 58, No. 2, 1991, pp. 277-297. http://dx.doi.org/10.2307/2297968

[10] D. Acemoglu, S. Johnson and J. Robinson, "Colonial Origins of Comparative Development: An Empirical Investigation," American Economic Review, Vol. 91, No. 5, 2001, pp. 1369-1401.

[11] N. Nunn, "The Long-term Effects of Africa's Slave Trades," Quarterly Journal of Economics, Vol. 123, No. 1, 2008, pp. 139-176. http://dx.doi.org/10.1162/qjec.2008.123.1.139

[12] D. Bloom and J. Sachs, "Geography, Demography and Economic Growth in Africa," Brookings Papers in Economic Activity, Vol. 1998, No. 2, 1998, pp. 207-273. http://dx.doi.org/10.2307/2534695

[13] A. K. Fosu, "Growth of African Economies: Productivity, Policy Syndromes and the Importance of Institutions," CSAE Working Paper, WPS/2012_11, 2012. 


\section{Appendices}

\section{Appendix 1. World Bank Country Policy and Institutional Assessments}

The World Bank instituted its Country Policy and Institutional Assessments (CPIA) in the late 1970s to help guide allocation of IDA resources to member countries using measurable indicators. The CPIA indicators assess the quality of a country's policy and institutional framework. The term "quality" refers to how conducive a country's framework is in fostering poverty reduction, sustainable growth, and the effective use of development assistance. The CPIA indicators have four broad clusters: A) economic management, B) structural policies, C) policies for social inclusion/equity, and D) public sector management and institutions. Cluster A measures policy indicators on macroeconomic management, fiscal policy, and debt policy; cluster B measures policy indicators on trade, financial sector and business regulatory environment; cluster $\mathrm{C}$ measures policies on gender equality, equity of public resource use, building human resources, social protection and labor and institutions for environmental sustainability; and cluster D measures policy indicators on property rights and rule-based governance, quality of budgetary and financial management, efficiency of revenue mobilization, quality of public admini- stration and transparency, accountability, and corruption in the public sector. Each cluster has key indicators that are scored/ranked in the range of 0 (low) to 6 (high) performance in two assessment phases.

The initial assessment, called the benchmarking phase, helps ensure that, given the criteria, the ratings are set at the right level and are consistent across countries and regions. The set of benchmark countries is reviewed every year. The second assessment phase is conducted by the World Bank country teams who prepare ratings proposals that are accompanied by a written justification. These proposals are sometimes participatory (joint assessment involving country authorities) and are reviewed within the respective region and subjected to Bank-wide review. The CPIA report shows a lowest and highest average overall score on macroeconomic management and business regulatory environment of 0 and 4.5 respectively for the various country groupings (Table A1). Although Sierra Leone's overall CPIA performance is weak, it stands tall on macroeconomic management and business regulatory environment (Figure A1).

Sierra Leone performed better than LICs and SSA averages on macroeconomic management, and its performance on the business regulatory environment exceeds the average for SSA countries.

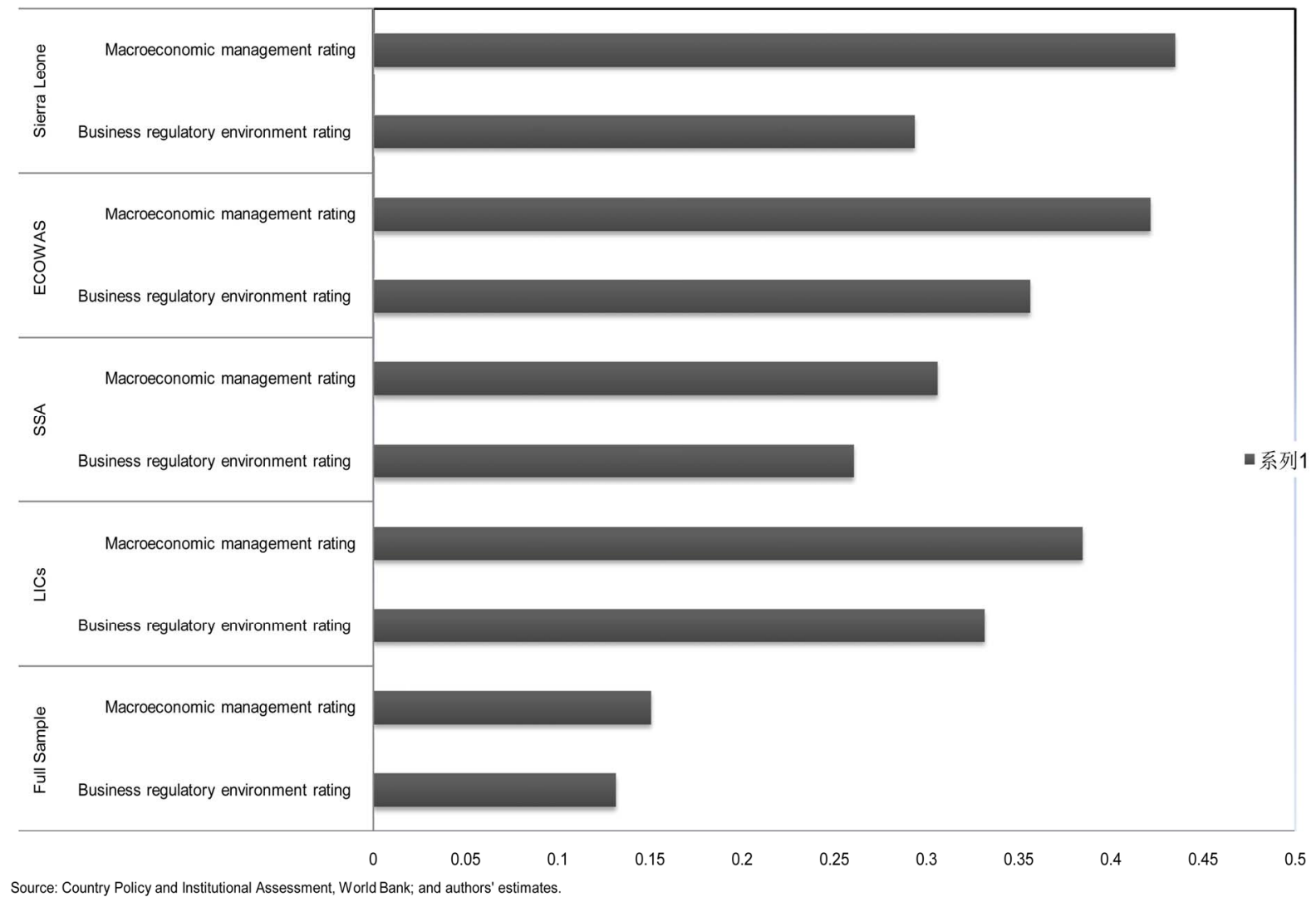

Figure A1. CPIA: Macroeconomic management and business regulatory environment, (average 2004-2010). 
Table A1. Summary country policy and institutional assessment, 2004-2010.

\begin{tabular}{|c|c|c|c|c|c|}
\hline CPIA Cluster & CPIA Indicator & Mean & Standard Deviation & Minimum & Maximum \\
\hline \multicolumn{6}{|l|}{ I. Full Sample } \\
\hline Cluster A & Macroeconomic management rating & 0.15 & 0.75 & 0.00 & 4.50 \\
\hline Cluster B & $\begin{array}{l}\text { Business regulatory environment rating } \\
\text { II. Low Income Countries }\end{array}$ & 0.13 & 0.65 & 0.00 & 4.50 \\
\hline Cluster A & Macroeconomic management rating & 0.38 & 1.15 & 0.00 & 4.50 \\
\hline Cluster B & $\begin{array}{l}\text { Business regulatory environment rating } \\
\text { III. Sub-Saharan African Countries }\end{array}$ & 0.33 & 1.00 & 0.00 & 4.50 \\
\hline Cluster A & Macroeconomic management rating & 0.31 & 1.03 & 0.00 & 4.50 \\
\hline Cluster B & Business regulatory environment rating & 0.26 & 0.88 & 0.00 & 4.00 \\
\hline \multicolumn{6}{|l|}{ IV. Sierra Leone } \\
\hline Cluster A & Macroeconomic management rating & 0.43 & 1.26 & 0.00 & 4.00 \\
\hline Cluster B & Business regulatory environment rating & 0.29 & 0.85 & 0.00 & 3.00 \\
\hline
\end{tabular}

Source: Country Policy and Institutional Assessment, World Bank; and authors' calculations.

\section{Appendix 2. Sample Country Groupings and Data Sources.}

Table A2. Country groupings, variable description, and data source.

\begin{tabular}{|c|c|c|c|c|}
\hline \multirow{2}{*}{$\begin{array}{c}\text { Advanced Economies } \\
\text { Australia }\end{array}$} & \multicolumn{2}{|c|}{ Low-Income Countries } & \multicolumn{2}{|l|}{ Sub-Saharan African } \\
\hline & Afghanistan & Macedonia, FYR & Angola & Senegal \\
\hline Austria & Armenia & Malawi & Benin & Seychelles \\
\hline Belgium & Bangladesh & Maldives & Botswana & Sierra Leone \\
\hline Canada & Benin & Mali & Burkina Faso & South Africa \\
\hline Cyprus & Bhutan & Mauritania & Burundi & South Sudan \\
\hline Czech Republic & Bolivia & Moldova & Cameroon & Sudan \\
\hline Estonia & Burundi & Mozambique & Central African Republic & Tanzania \\
\hline Finland & Cambodia & Myanmar & Chad & Togo \\
\hline France & Cameroon & Nepal & Comoros & Uganda \\
\hline Germany & Cape Verde & Nicaragua & Republic of the Congo & Zambia \\
\hline Greece & Central African Republic & Niger & Democratic Republic of the Congo & Zimbabwe \\
\hline Hong Kong SAR & Chad & Nigeria & Cote d'Ivoire & \\
\hline Ireland & Congo, Dem. Rep. & Rwanda & Equatorial Guinea & \\
\hline Israel & Congo, Rep. & Samoa & Eritrea & \\
\hline Italy & Cote d'Ivoire & Sao Tome and Principe & Ethiopia & \\
\hline Japan & Djibouti & Senegal & Gabon & \\
\hline Korea & Dominica & Sierra Leone & The Gambia & \\
\hline Luxembourg & Eritrea & Solomon Islands & Ghana & \\
\hline Malta & Ethiopia & Somalia & Guinea & \\
\hline Netherlands & Gambia, The & St. Lucia & Guinea-Bissau & \\
\hline New Zealand & Georgia & St. Vincent and the Grenadines & Kenya & \\
\hline Norway & Ghana & Sudan & Lesotho & \\
\hline Portugal & Grenada & Tajikistan & Liberia & \\
\hline Singapore & Guinea & Tanzania & Madagascar & \\
\hline Slovak Republic & Guinea-Bissau & Timor-Leste & Malawi & \\
\hline Sweden & Honduras & Uganda & Mauritius & \\
\hline Switzerland & Kenya & Uzbekistan & Mozambique & \\
\hline Taiwan Province of China & Kiribati & Vanuatu & Namibia & \\
\hline United Kingdom & Kyrgyz Republic & Vietnam & Niger & \\
\hline \multirow[t]{3}{*}{ United States } & Lao People's Dem.Rep & Yemen, Rep. & Nigeria & \\
\hline & Lesotho & Zambia & Rwanda & \\
\hline & Liberia & Zimbabwe & Sao Tome and Principe & \\
\hline
\end{tabular}

Source: Countries classifications come from World Economic Outlook (IMF). 
Table A3. Variables description and sources of data.

\begin{tabular}{|c|c|c|}
\hline Variables & Description & Sources of Data \\
\hline $\begin{array}{l}\text { Log. Real GDP per } \\
\text { capita }\end{array}$ & Natural logarithm of real output/GDP per capita. & $\begin{array}{l}\text { World Economic Outlook (IMF), } \\
\text { and authors calculations }\end{array}$ \\
\hline $\begin{array}{l}\text { One-period lagged per } \\
\text { capita real GDP }\end{array}$ & $\begin{array}{l}\text { Natural logarithm of one-period lagged } \\
\text { real GDP per capita. }\end{array}$ & $\begin{array}{l}\text { World Economic Outlook (IMF), } \\
\text { and authors calculations }\end{array}$ \\
\hline Capital stock & $\begin{array}{l}\text { Natural logarithm of capital-labour ratio net of depreciation of } \\
\text { previous period's capital stock plus gross fixed capital accumulation. }\end{array}$ & $\begin{array}{l}\text { World Economic Outlook (IMF), } \\
\text { and authors calculations }\end{array}$ \\
\hline Openness & $\begin{array}{l}\text { Natural logarithm of economic openness. The sum of imports plus export divided } \\
\text { by nominal GDP, (captures the extent to which a country trades with rest of world). }\end{array}$ & $\begin{array}{l}\text { World Economic Outlook (IMF), } \\
\text { and authors calculations }\end{array}$ \\
\hline Inflation variability & Natural logarithm of the deviation of inflation from the trend (mean) in 1960-70. & $\begin{array}{l}\text { World Economic Outlook (IMF), } \\
\text { and authors calculations }\end{array}$ \\
\hline REER & Natural logarithm of real effective exchange rate. & $\begin{array}{l}\text { World Economic Outlook (IMF), } \\
\text { and authors calculations }\end{array}$ \\
\hline Credit boom & $\begin{array}{l}\text { Natural logarithm of two standard deviations of real private sector } \\
\text { credit from the trend (mean) in } 1960-70 .\end{array}$ & $\begin{array}{l}\text { World Economic Outlook (IMF), } \\
\text { and authors calculations }\end{array}$ \\
\hline Government consumption & $\begin{array}{c}\text { Natural logarithm of real government consumption (i.e. public } \\
\text { spending on wages and salaries, transfers and goods and services). }\end{array}$ & $\begin{array}{l}\text { World Economic Outlook (IMF), } \\
\text { and authors calculations }\end{array}$ \\
\hline
\end{tabular}

\section{Appendix 3. Role of Institutions in Per Capita Real GDP Growth, 1960-2010.}

Table A4. Role of institutions in growth, 1960-2010.

\begin{tabular}{|c|c|c|c|c|c|c|}
\hline \multicolumn{7}{|l|}{ A. Full Sample } \\
\hline \multicolumn{7}{|l|}{ Dependent variable: log. Real GDP per capita } \\
\hline & \multicolumn{2}{|c|}{$\begin{array}{c}\text { Quality of Structural } \\
\text { Policies }\end{array}$} & \multicolumn{2}{|c|}{$\begin{array}{l}\text { Business Regulatory } \\
\text { Environment }\end{array}$} & \multicolumn{2}{|c|}{$\begin{array}{l}\text { Overall Economic } \\
\text { Management }\end{array}$} \\
\hline & $\begin{array}{l}\text { Below } \\
\text { Average }\end{array}$ & $\begin{array}{l}\text { Above } \\
\text { Average }\end{array}$ & $\begin{array}{l}\text { Below } \\
\text { Average }\end{array}$ & $\begin{array}{l}\text { Above } \\
\text { Average }\end{array}$ & $\begin{array}{l}\text { Below } \\
\text { Average }\end{array}$ & $\begin{array}{l}\text { Above } \\
\text { Average }\end{array}$ \\
\hline \multirow[t]{2}{*}{ One-period lagged per capita real GDP } & $0.923^{* * *}$ & $0.864^{* * *}$ & $0.923^{* * *}$ & $0.848^{* * *}$ & $0.923^{* * *}$ & $0.898^{* * *}$ \\
\hline & $(0.000)$ & $(0.000)$ & $(0.000)$ & $(0.001)$ & $(0.000)$ & $(0.000)$ \\
\hline \multirow[t]{2}{*}{ Capital stock } & $0.064^{* *}$ & $0.024^{*}$ & $0.064^{* *}$ & 0.0053 & $0.064^{* * *}$ & $0.034^{* * *}$ \\
\hline & $(0.054)$ & $(0.101)$ & $(0.054)$ & $(0.391)$ & $(0.054)$ & $(0.020)$ \\
\hline \multirow[t]{2}{*}{ Inflation variability } & $-0.002^{*}$ & -0.000 & $-0.00^{2^{*}}$ & 0.0003 & $-0.002^{*}$ & -0.0003 \\
\hline & $(0.060)$ & $(0.853)$ & $(0.060)$ & $(0.816)$ & $(0.060)$ & $(0.810)$ \\
\hline \multirow[t]{2}{*}{ REER } & -0.001 & -0.0012 & -0.0006 & $-0.005^{* *}$ & -0.0006 & $-0.003^{* *}$ \\
\hline & $(0.056)$ & $(0.567)$ & $(0.563)$ & $(0.144)$ & $(0.563)$ & $(0.066)$ \\
\hline \multirow[t]{2}{*}{ Credit boom } & 0.0185 & -0.0079 & 0.0185 & -0.0054 & 0.0185 & -0.0013 \\
\hline & $(0.125)$ & $(0.257)$ & $(0.125)$ & $(0.449)$ & $(0.125)$ & $(0.795)$ \\
\hline \multirow[t]{2}{*}{ Government consumption } & 0.0092 & $0.029^{* *}$ & 0.0092 & $0.046^{* * *}$ & 0.0092 & $0.027^{* * *}$ \\
\hline & $(0.414)$ & $(0.057)$ & $(0.414)$ & $(0.051)$ & $(0.414)$ & $(0.001)$ \\
\hline \multirow[t]{2}{*}{ Constant } & $0.668^{*}$ & $1.259^{* * *}$ & $0.668^{*}$ & $1.334^{* * *}$ & $0.668^{*}$ & $0.933^{* * *}$ \\
\hline & $(0.063)$ & $(0.002)$ & $(0.063)$ & $(0.067)$ & $(0.063)$ & $(0.000)$ \\
\hline Number of observations & 933 & 222 & 933 & 86 & 933 & 331 \\
\hline R-squared & 0.9801 & 0.9256 & 0.9801 & 0.937 & 0.9801 & 0.9246 \\
\hline F statistic & 6595.87 & 822.14 & 6595.87 & .... & 6595.87 & 1304.23 \\
\hline Prob $>$ F & 0.0000 & 0.0000 & 0.0000 & $\ldots$ & 0.0000 & 0.0000 \\
\hline
\end{tabular}

Source: IMF World Economic Outlook (WEO) database; and authors' estimations using panel methods in Stata. Notes: All variables are expressed in logarithms. Figures in parenthesis are probability values; note: ${ }^{* * *} \mathrm{p}<0.01,{ }^{* *} \mathrm{p}<0.05,{ }^{*} \mathrm{p}<0.1$. 
Table A5. Role of institutions in growth, 1960-2010.

\begin{tabular}{|c|c|c|c|c|c|c|}
\hline \multicolumn{7}{|l|}{ B. Low-Income Countries } \\
\hline \multicolumn{7}{|l|}{ Dependent variable: log. Real GDP per capita } \\
\hline & \multicolumn{2}{|c|}{$\begin{array}{c}\text { Quality of Structural } \\
\text { Policies }\end{array}$} & \multicolumn{2}{|c|}{$\begin{array}{l}\text { Business Regulatory } \\
\text { Environment }\end{array}$} & \multicolumn{2}{|c|}{$\begin{array}{l}\text { Overall Economic } \\
\text { Management }\end{array}$} \\
\hline & $\begin{array}{c}\text { Below } \\
\text { Average }\end{array}$ & $\begin{array}{l}\text { Above } \\
\text { Average }\end{array}$ & $\begin{array}{c}\text { Below } \\
\text { Average }\end{array}$ & $\begin{array}{c}\text { Above } \\
\text { Average }\end{array}$ & $\begin{array}{c}\text { Below } \\
\text { Average }\end{array}$ & $\begin{array}{l}\text { Above } \\
\text { Average }\end{array}$ \\
\hline \multirow[t]{2}{*}{ One-period lagged per capita real GDP } & $0.895^{* * *}$ & $0.840^{* * *}$ & $0.895^{* * *}$ & $0.711^{* * *}$ & $0.895^{* * *}$ & $0.871^{* * *}$ \\
\hline & $(0.061)$ & $(0.000)$ & $(0.061)$ & $(0.001)$ & $(0.061)$ & $(0.000)$ \\
\hline \multirow[t]{2}{*}{ Capital stock } & $0.088^{*}$ & $0.026^{*}$ & $0.088^{*}$ & 0.0073 & $0.088^{*}$ & $0.033^{* * *}$ \\
\hline & $(0.046)$ & $(0.091)$ & $(0.046)$ & $(0.216)$ & $(0.046)$ & $(0.023)$ \\
\hline \multirow[t]{2}{*}{ Inflation variability } & $-0.003^{* *}$ & $-0.000^{* *}$ & $-0.003^{* *}$ & -0.0027 & $-0.003^{* *}$ & -0.000 \\
\hline & $(0.001)$ & $(0.082)$ & $(0.001)$ & $(0.930)$ & $(0.001)$ & $(0.814)$ \\
\hline \multirow[t]{2}{*}{ REER } & -0.001 & -0.0003 & -0.001 & $-0.006^{* *}$ & -0.001 & $-0.003^{* *}$ \\
\hline & -0.001 & $(0.877)$ & $(0.001)$ & $(0.220)$ & $(0.001)$ & $(0.090)$ \\
\hline \multirow[t]{2}{*}{ Credit boom } & $(0.001)$ & $0.009^{*}$ & $0.050^{*}$ & -0.0034 & $0.050^{*}$ & -0.0013 \\
\hline & $(0.027)$ & $(0.247)$ & $(0.027)$ & $(0.670)$ & $(0.027)$ & $(0.792)$ \\
\hline \multirow[t]{2}{*}{ Government consumption } & 0.004 & 0.0290 & 0.004 & $0.050^{* * *}$ & 0.004 & $0.027^{* * *}$ \\
\hline & $(0.013)$ & $(0.082)$ & $(0.013)$ & $(0.171)$ & $(0.013)$ & $(0.002)$ \\
\hline \multirow[t]{2}{*}{ Constant } & 0.868 & 1.4704 & 0.868 & $2.455^{* * *}$ & 0.868 & $0.983^{* * *}$ \\
\hline & $(0.561)$ & $(0.001)$ & $(0.561)$ & $(0.001)$ & $(0.561)$ & $(0.000)$ \\
\hline Number of observations & $\ldots$ & 194 & $\ldots$ & 58 & $\ldots$ & 303 \\
\hline R-squared & $\ldots$ & 0.8977 & $\ldots$ & 0.8084 & $\ldots$ & 0.9246 \\
\hline F statistic & $\ldots$ & 82336.05 & $\ldots$ & $\ldots$ & $\ldots$ & 904.47 \\
\hline Prob $>$ F & $\ldots$ & 0.0000 & $\ldots$ & $\ldots$ & $\ldots$ & 0.0000 \\
\hline
\end{tabular}

Source: IMF World Economic Outlook (WEO) database; and authors' estimations using panel methods in Stata. Notes: All variables are expressed in logarithms. Figures in parenthesis are standard errors; note: ${ }^{* * *} \mathrm{p}<0.01,{ }^{* *} \mathrm{p}<0.05,{ }^{*} \mathrm{p}<0.1$.

Table A6. Role of institutions in growth, 1960-2010.

\begin{tabular}{|c|c|c|c|c|c|c|}
\hline \multicolumn{7}{|l|}{ C. Sub-Saharan African Countries } \\
\hline \multicolumn{7}{|l|}{ Dependent variable: log. Real GDP per capita } \\
\hline & \multicolumn{2}{|c|}{$\begin{array}{c}\text { Quality of Structural } \\
\text { Policies }\end{array}$} & \multicolumn{2}{|c|}{$\begin{array}{c}\text { Business Regulatory } \\
\text { Environment }\end{array}$} & \multicolumn{2}{|c|}{$\begin{array}{c}\text { Overall Economic } \\
\text { Management }\end{array}$} \\
\hline & $\begin{array}{c}\text { Below } \\
\text { Average }\end{array}$ & $\begin{array}{c}\text { Above } \\
\text { Average }\end{array}$ & $\begin{array}{c}\text { Below } \\
\text { Average }\end{array}$ & $\begin{array}{c}\text { Above } \\
\text { Average }\end{array}$ & $\begin{array}{c}\text { Below } \\
\text { Average }\end{array}$ & $\begin{array}{c}\text { Above } \\
\text { Average }\end{array}$ \\
\hline One-period lagged per capita real GDP & $0.735^{* * *}$ & $0.865^{* * *}$ & $0.735^{* * *}$ & $0.711^{* * *}$ & $0.735^{* * *}$ & $0.903^{* * *}$ \\
\hline \multirow[t]{2}{*}{ Capital stock } & $0.206^{* * *}$ & $0.030^{* *}$ & $0.206^{* * *}$ & $0.007^{*}$ & $0.206^{* * *}$ & $0.357^{* * *}$ \\
\hline & $(0.060)$ & $(0.079)$ & $(0.060)$ & $(0.216)$ & $(0.060)$ & $(0.280)$ \\
\hline \multirow[t]{2}{*}{ Inflation variability } & 0.0007 & 0.0082 & 0.0007 & -0.0003 & 0.0007 & -0.0014 \\
\hline & $(0.932)$ & $(0.705)$ & $(0.932)$ & $(0.930)$ & $(0.932)$ & $(0.942)$ \\
\hline \multirow[t]{2}{*}{ REER } & 0.0018 & -0.0069 & 0.0018 & $-0.006^{*}$ & 0.0018 & $-0.028^{*}$ \\
\hline & $(0.851)$ & $(0.787)$ & $(0.851)$ & $(0.220)$ & $(0.851)$ & $(0.090)$ \\
\hline Credit boom & $(0.111)$ & $(0.295)$ & $(0.111)$ & $(0.670)$ & $(0.111)$ & $(0.604)$ \\
\hline \multirow[t]{2}{*}{ Government consumption } & -0.0957 & 0.0173 & -0.0096 & 0.0500 & -0.0066 & $0.025^{* * *}$ \\
\hline & $(0.842)$ & $(0.330)$ & $(0.842)$ & $(0.171)$ & $(0.842)$ & $(0.004)$ \\
\hline \multirow[t]{2}{*}{ Constant } & $1.941^{* * *}$ & $1.325^{* * *}$ & $1.941^{* * *}$ & $2.455^{* * *}$ & $1.941^{* * *}$ & $0.912^{* * *}$ \\
\hline & $(-0.121)$ & $(0.003)$ & $(0.121)$ & $(0.001)$ & $(0.121)$ & $(0.000)$ \\
\hline Number of observations & 55 & 145 & 55 & 58 & 55 & 236 \\
\hline R-squared & 0.9874 & 0.9150 & 0.9874 & 0.8084 & 0.9874 & 0.9243 \\
\hline F statistic & $\cdots$ & $\cdots$ & $\cdots$ & $\cdots$ & $\cdots$ & 1775.60 \\
\hline Prob $>$ F & $\ldots$ & $\ldots$ & $\ldots$ & $\ldots$ & $\ldots$ & 0.0000 \\
\hline
\end{tabular}

Source: IMF World Economic Outlook (WEO) database; and authors' estimations using panel methods in Stata. Notes: All variables are expressed in logarithms. Figures in parenthesis are probability values; note: ${ }^{* * *} \mathrm{p}<0.01,{ }^{* *} \mathrm{p}<0.05,{ }^{*} \mathrm{p}<0.1$. 